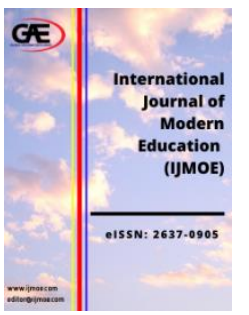

INTERNATIONAL JOURNAL OF

MODERN EDUCATION

(IJMOE)

www.ijmoe.com

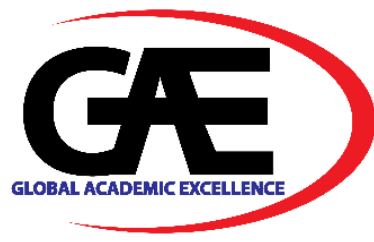

\title{
GAME-BASED MOBILE APPLICATION (P-KSSMPKPS) REMEDIAL INSTRUCTION IN FRACTION LEARNING: BEST PRACTICES TO TEACHING AND LEARNING PERFORMANCE ON STUDENTS WITH LEARNING DISABILITIES
}

\author{
Murugesu Supermaniam ${ }^{1 *}$, Rozniza Zaharudin ${ }^{2 *}$ \\ 1 School of Educational Studies, Universiti Sains Malaysia, Malaysia \\ Email: murugesu2012@gmail.com \\ 2 School of Educational Studies, Universiti Sains Malaysia, Malaysia \\ Email: roz@usm.my \\ * Corresponding Author
}

\section{Article Info:}

Article history:

Received date: 18.07.2021

Revised date: 19.08 .2021

Accepted date: 02.09.2021

Published date: 10.09.2021

\section{To cite this document:}

Supermaniam, M., \& Zaharudin, R. (2021). Game-Based Mobile Application (P-KSSMPKPS) Remedial Instruction In Fraction Learning: Best Practices To Teaching And Learning Performance On Students With Learning Disabilities. International Journal of Modern Education, 3(10), 94-110.

DOI: $10.35631 / \mathrm{IJMOE.310008}$

\begin{abstract}
:
This research was carried out to investigate the efficacy of the creative gamebased mobile learning application (P-KSSMPKPS) in addressing students with learning disabilities in the discipline topic. A total of 152 students from ten different schools in the South Kinta district in Perak, Malaysia, divided into experimental group and control groups were used: (1) traditional teaching methods, (2) as the best instructional case we could implement, teaching with a mobile game-based learning application (P-KSSMPKPS) who had participated in this survey. The study was conducted based on the mixed experimental design in which each respondent was given pre-test, treatment, and post-test. The mobile application developed is a treatment method used due to its educational advantages that impact long-term memory. The development of this mobile application incorporates multimedia and visual elements that enable the attention of disadvantaged students to explore and follow the learning process through to the end of learning. This mobile application has been implemented and tested for its effectiveness on student achievement after learning for a fraction of mobile apps developed. As a result of this mobile application, it was found that student achievement improved and resolved further errors in the students. These results open a new performance enhancement using creative fraction (P-KSSMPKPS) game-based learning as remedial instruction to students with learning problems.
\end{abstract}




\section{Introduction}

Basically, in the mathematics component, the main goal is to provide special need students with the opportunity to learn the concept of numbers, compare values, solve problem-solving, listen, and speak. Although these are necessary abilities, many have not yet mastered them and have been diagnosed with a mathematical learning disability (MLD) (Furlong, McLoughlin, McGilloway, Geary \& Butterworth, 2015). Mobile game-based learning approaches can positively impact students' learning and learning processes (Zaibon, 2015). It is because of moving information from a static book to a new, more interesting, dynamic, and interactive learning pattern with the help of new media such as audio, video, animation, and graphics. Sutaji (2015) states that multimedia-based learning can provide a more interactive learning situation between students and their learning content. This process will speed up the process of teaching and learning. This method is advantageous and can guide and shape students' thinking and thinking to be more creative and understand knowledge more effectively.

The primary learning scenario of mathematical solutions has begun to shift from using lowlevel technology to multimedia-based methods. Primarily, educators involved with these special need's groups should produce activities or teaching aids appropriate to the variety of disabilities experienced by students under their guidance. Also, multimedia software in learning was primarily based on subjects involving various subtopics that can help students. It is a burden for special education students because they have difficulty receiving much input at a time. According to the Persons with Disabilities Act 2008 (the Act), there are seven categories of persons with disabilities under which they can be registered: hearing disability, visual disability, speech disability, physical disability, learning disability, mental disability, and multiple disabilities. A learning disability is defined as a disruption in one or more of the critical learning processes involved in comprehension or the use of language, whether spoken or written, which can affect one's ability to listen, read, write, spell, or do arithmetic. According to Butterworth (2013), learning difficulties are issues that affect the brain's ability to receive, process, and store information. Learning disabilities are caused by contrast in brain structure and capability that affect a person's ability to receive, store, process, recover, or transmit data (National Center for Learning Disabilities, 2014). The most well-known types of learning difficulties are those that affect reading (Dyslexia), math (Dyscalculia), and writing (Dyscalculia) (Dysgraphia). Fortunately, in today's technological environment, we have various options for teaching and strengthening core reading, writing, and math skills. As multimedia learning software can positively impact mathematics learning disabilities, several researchers (Chiu \& Churchill, 2015; Rau, Aleven \& Rummel, 2015; Shin \& Bryant, 2015) have conducted studies on its use in schools. Therefore, researchers have also developed gamebased mobile application learning tools (P-KSSMPK) to help students with mathematical learning difficulties (MLD) learn and solve fraction skills faster and faster.

This mobile app (P-KSSMPKPS) is essential for special education students with learning disabilities as it will guide them in solving difficult fraction topics because of their low 
cognitive level. According to Echazarra, Salinas, Mendez, Denis and Rech (2016), students can remember something from what they see 20 per cent, 30 per cent of what they listen to, and 60 to 70 per cent of the interactions around them. It shows that students need a composition of what they hear, see and what happens around them to gain more effective results and understanding of a subject in the learning process. Teaching materials presented in various media such as text, voice, images, graphics, and even animations will interest students to stay focused during the learning and facilitate the process instead of the more static textbooks. Students can learn anywhere through this mobile application, hoping that learning at school can be remembered well. The creation of this mobile app (P-KSSMPK) will not only benefit students, but also special education teachers will benefit. With these mobile apps, parents, guardians, and teachers do not have to worry about student self-review methods at home as they will act as 'home teachers' as it contains audio and visual displays that enable students to repeat. Besides, teachers can also act as facilitators to students during the teaching and learning process. The present study is part of a greater systematic process to create a standardised procedure for conducting game-based mobile learning application effectiveness studies. During the first phase, the variety of methods used for sampling, intervention implementation, measures, and data analysis was mapped using Cochrane guidelines in a systematic literature review (Higgins, Green \&Collaboration, 2008).

\section{Literature Review}

MLD is characterised by a lack of mastery of one or more fields of mathematics, ranging from fundamental number skills to more complex algebra and geometry. Until far, most of the research on MLD has been on the inability to acquire proficiency in more fundamental mathematical abilities rather than in more advanced areas. (2013) (Fischer). Nonetheless, individuals with mathematical learning difficulties (MLD) often struggle with fractions issues (Lewis \& Lynn, 2018; Ikhwanudin \& Suryadi, 2018). These difficulties stem from the demands of word problem solving, which include the ability to read and comprehend situations represented by various schema (e.g., compare, change, and combine addition and subtraction problem types), translate the schema to mathematical equations, or perform a series of computations (Shin \& Bryant, 2017). A schema is a framework or structure for expressing data, and it is critical for fractions problem solving (Hunt, Welch-Ptak \& Silva, 2016). Students may improve their problem-solving abilities by modelling or depicting the problem's structure using a diagram or graphic organiser (Dennis, Knight \& Jerman, 2016; Sharp \& Shih Dennis, 2017).

Consider a fractions issue involving double the amount of flour in a baking recipe. Students must grasp multiplicative reasoning, fraction multiplication, and the connection between fractions (Ervin, 2017; Simon, Kara, Norton \& Placa, 2018). Thus, fractions with varying schema may be difficult for students with MLD to solve since they need an accurate interpretation and representation of the problem's structure. Along with difficulties with fractions problem solving, research has revealed that students with MLD struggle with conceptual (i.e., comprehension of the ideas associated with a mathematical topic and their relationships) and procedural (i.e., performing a sequence of steps and operations) understanding when it comes to solving algebraic problems with fractions (Sumpter \& Eriksson, 2021; Yang \& Sianturi, 2020; Rodrigues, Dyson, Hansen \& Jordan, 2016). Students with MLD need extensive instructional assistance to improve their understanding of fraction concepts (Shin \& Bryant, 2015; Shin \& Bryant, 2017). 
Finally, incorporating multimedia virtual manipulatives into game-based mobile apps is another effective method for teaching children with MLD to solve fractions (Rau, Aleven \& Rummel, 2015; Shin \& Bryant, 2015). Virtual manipulatives are interactive visual representations that enable students to convert visual models into problem-solving scenarios (Hakim, Alghadari \& Widodo, 2019; Shin \& Bryant, 2017; Shin, Simon, Meador, Goode, Deal \& Jackson, 2021). Researchers have advocated for the use of multimodal visual representations and manipulatives to assist pupils in solving fraction issues (Shin \& Bryant, 2015; AndersonPence \& Moyer-Packenham, 2015). Children with MLD have difficulty mapping or diagramming the connections between quantities in mathematical problem structures (Zhang, \& Zhou, 2016; Nelson, Hunt, Martin, Patterson \& Khounmeuang, 2020). Agrawal and Morin (2016) examined the impact of the concrete-representational-abstract sequence on solving mathematical problems involving fractions via virtual manipulatives. The findings indicated that five fifth-grade students with MD and LD improved significantly throughout the intervention period than the baseline (percentage of all non-overlapping data $=91$ per cent). Thus, the use of virtual manipulatives can help students conceptualise and solve algebraic problems involving fractions (McNeary, 2020; Shin \& Bryant, 2017). Despite evidence of the benefits of cognitive and metacognitive techniques and virtual manipulatives, no mobile application integrates these two components into teaching middle school children with MLD fractions problem-solving. We devised and created a game-based mobile application for PKSSMPKPS fraction remedial teaching to answer this research requirement. All examples in P-KSSMPKPS were culled from mathematics textbooks and publications devoted to fraction instruction (Hoch, Reinhold, Werner, Richter-Gebert \& Reiss, 2018; Yang, 2018). The present research examined the impact of a multi-component P-KSSMPKPS on secondary school pupils with MLD to solve fractions problems. The following research questions drove the study:

\section{Purpose Of This Study and Research Questions}

This study was conducted to test the effectiveness of a mobile educational application and creative fraction game-based learning for students with learning disabilities as a motivating device to increase fraction interest, knowledge, and achievements. The researcher created a creative game-based mobile learning application(P-PKSSMPK) based on the high school special education student syllabus to explore this issue (Zaibon, 2015). Thus, the main research question is:

RQ1.1. In what ways do the traditional teaching methods (low-grade innovation) improve student's achievement in fraction knowledge?

RQ1.2. In what ways do the game-based mobile application (P-PKSSMPK) remedial instruction improve student's achievement in fraction knowledge?

The third purpose was to investigate the instructive properties of the game-based mobile application (learning execution). First, we accept that the game can uncover the traditional (low-grade innovations) teaching method more unmistakably to students. From here on out, we will allude to this subject as students' interest. Accordingly, we likewise propose this supplemental research question. 


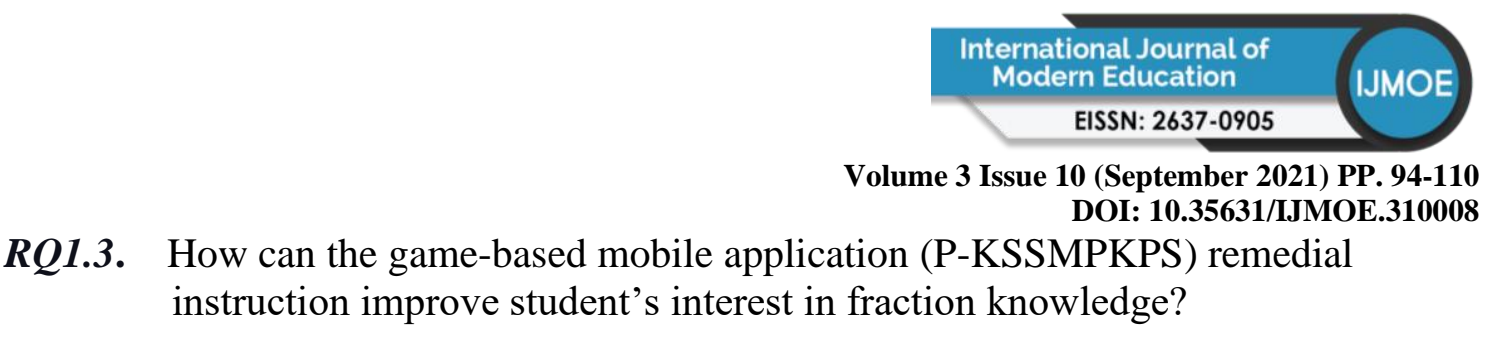

The most widely recognized informative way to deal with teaching fractions is the teacher, generally through lectures. Constant guidance is the typical channel where students hear and find out about fractions. Additionally, in instructive mobile application games experiments, the impacts of the mobile application games are generally contrasted with constant guidance, following a regular exploratory gathering versus control group approach. Accordingly, we follow this same arrangement for the experiment where the maximum control group we picked to contrast and the game was teaching by the students' usual educator.

In any case, utilizing just one control group typically limits the discussion on the size impact since the game's impact can only contrast to a bottom-line control mensuration. Also, this perspective raises worries about whether the game (P-KSSMPKPS) caused the development in interest or whether it was only a by-product of presenting a mobile application game in the classroom. For those reasons, we set off to contrast game-based learning with regular guidance, and another approach it very well may be outflanked. This approach gave us a top line to contrast with and a guide to eliminating the predisposition presented by regular guidance.

\section{Methodology}

According to previous research, mobile applications can improve academic performance when used appropriately (Allen, 2011). Therefore, the experimental group received an educational mobile app game in this study, while the control group received traditional teaching methods. The study's goal was to see if both approaches to instruction were effective and capable of increasing the effectiveness of improving students' achievement knowledge. In addition, the study investigated the interest of mobile application-based remedial instruction in fraction learning enhancement using a customised P-KSSMPKPS game that teaches.

\section{Participants}

The study involved 152 high school students from 10 different schools in the Perak region, Malaysia. All the students from Special Need Public Schools of Perak region, Malaysia. The gender proportion in the resulting population $(\mathrm{N}=76)$ was $50 \%$ females and $50 \%$ males. The median age was 14 . All students were given a letter of consent to participate voluntarily without coercion. Since the students were under 18 years of age, parental confirmation was also obtained before the students were involved in the study. In addition, the researcher also obtained permission from the education policy planning and research division, state education office, district education office and the school before obtaining data from all students. Students who were reluctant in this study were not coerced.

In terms of gender, age, and school distribution, this sample represents the student population in the Perak region for this age (Perak District Educational Offices, 2020). 99\% of students did not know the content of the play P-KSSMPKPS before the study; meanwhile, we counselled the educators not to discuss whatever was associated with its before the experiment. Students presented meagre achievement rates, which suggests low concentration in the subject. Table 1 depicts the distribution of participants by gender, intervention group, and school type. 


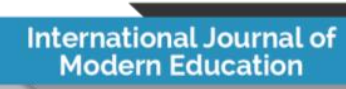

EISSN: 2637-0905

Volume 3 Issue 10 (September 2021) PP. 94-110

DOI: 10.35631/IJMOE.310008

Table 1: Demographics of Participants.

\begin{tabular}{lllll}
\hline Demographics & & $\begin{array}{l}\text { Game-based } \\
\text { instruction (EG) }\end{array}$ & $\begin{array}{l}\text { Traditional } \\
\text { instruction TG) }\end{array}$ & Total \\
\hline Gender & Male & $40(52.6 \%)$ & $36(47.4 \%)$ & $50 \%$ \\
& Female & $36(47.4 \%)$ & $40(52.6 \%)$ & $50 \%$ \\
Age (Mean) & & $13.86 \pm 1.47$ & $13.86 \pm 1.47$ & $13.86 \pm 1.47$ \\
Total & 76 & 76 & 152 \\
\hline
\end{tabular}

\section{Experimental Design}

The students were separated into two groups. One group of students played the game, and the other partial attended a lecture by the teacher. We used a randomisation procedure to confirm that the demographics of the two groups were as similar as possible and that students at the same school were evenly dispersed in-game groups (Experimental Group, EG) and control groups (Traditional Group, TG). Like the size of similar rooms provided by each school, a logistic extension made it bearable to distribute the same number of students to each group ( $\mathrm{N}=$ 76 for EG; and control groups $\mathrm{N}=76$ for $\mathrm{TG}$, with a total $\mathrm{N}=152$ in both groups).

The experiment was planned to be suitable for a secondary school class's ordinary time (60 min). All the students began filling out the same pre-test exam assessment (researchers will analyse the exam assessment in the questions) and instruments to measure students' achievement towards fractions. It took 40 minutes to complete. The post-test exam assessment contains the same instruments to determine the knowledge gain. Data from pre and post-test were unidentified to warrant the confidentiality of the students. Both tests were harmonising through numeric encryption that each student acknowledged at the commencement of the fraction. The complete descriptions of the exam assessment are included in section 3.3.2.

Then, students joined the sort of instruction they were allocated for a 40 min meeting. Students fitting to the teachers' groups (control groups) stayed in their regular classroom, while game group (experimental group) students went to the computer lab room. Students in control groups (TG) received a lesson about fractions from their usual teacher. Entirely the educational material used in the control group was provided by researchers to diminish differences produced by content and to confirm that all two instructional approaches roofed similar ideas. It involved a PowerPoint slides presentation as a backup medium to provision their teaching.

Students in the EG (game group) played the game P-KSSMPKPS underneath the direction of a researcher who did not transport any help but observed students' interface with the application. They could play as many times as they wanted during the class. Subsequently, the instruction, 40 min before the end of the class, all the students ended a post-test exam assessment with the same two instruments elaborate in the pre-test to ascertain gain.

Following the end of the post-test, the researcher conducts an interview session. Ten face-toface interviews were conducted. The authors conducted a review study from which the interview questions were derived. The interview was organised around four dimensions of Cochrane guidelines used in the literature review: 1) people who took part, 2) Interventions, 3) Methods, and 4) Outcome Measures. After learning from the authors ' content analysis, we added a fifth dimension, data analysis, that contrasts statistical techniques to quantify learning Copyright (C) GLOBAL ACADEMIC EXCELLENCE (M) SDN BHD - All rights reserved 


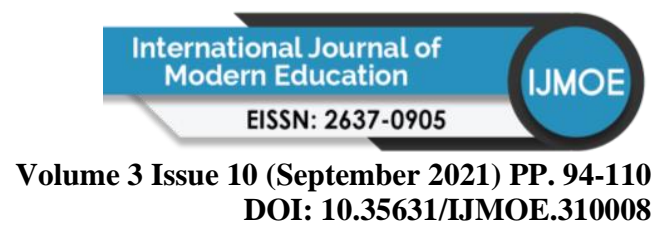

outcomes in game-based mobile application effectiveness studies. As a result, the interview was conducted along with five rather than four dimensions.

\section{Material and Instruments}

\section{Educational Mobile Application P-KSSMPKPS and Remedial Instruction}

To develop systems that meet users' needs, developers have chosen to develop software with visual and audio elements in the presentation of information that enables users to process information faster, longer and improve their learning level (Hegedus \& Moreno-Armella, 2020). This mobile application P-KSSMPKPS (Figure 1 - Figure 6), was developed using Android Studio 4.0 with java development kit (JDK 14) software as an authoring tool. Also, the system is developed with multimedia elements that enable the user's attention and interest to explore to the end and influence the user's motivation towards receiving information (Amir, Hasanah \& Musthofa, 2018).

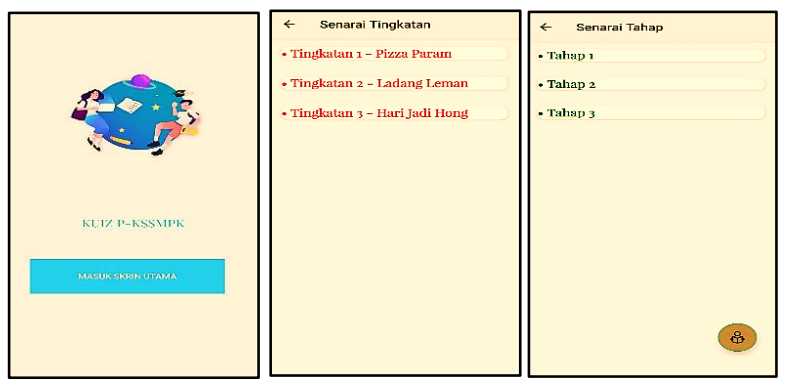

Figure 1: Start Stage in The Game
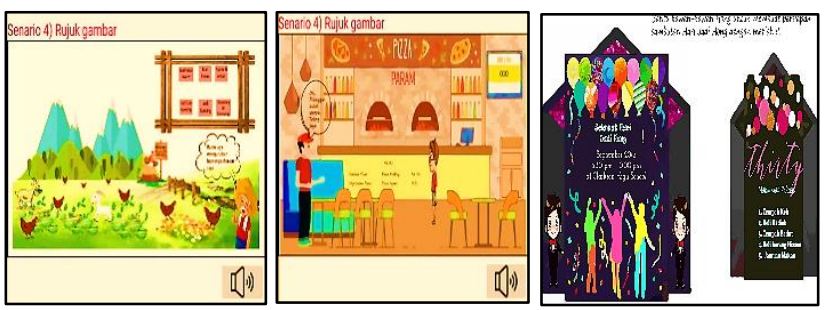

Figure 3: Storytelling Scenario in The Game
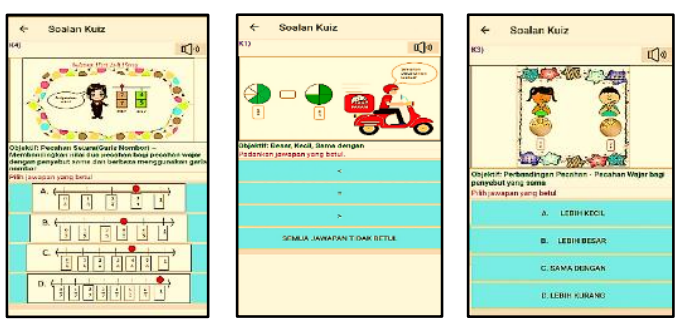

Figure 5: Snapshot of a Optional Question in The Game
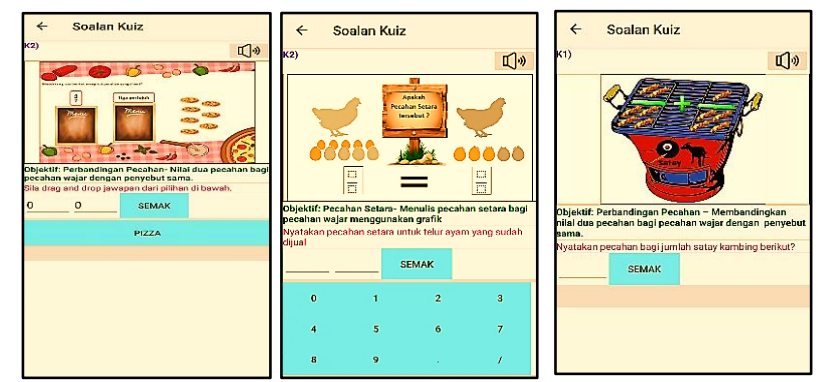

Figure 2: Snapshot of a Fill in Question in The Game
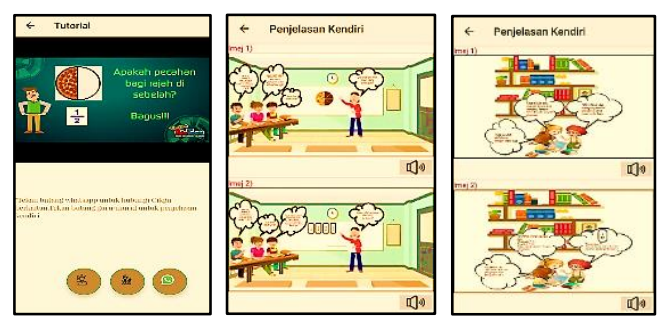

Figure 4: Self-Explanatory in The Game
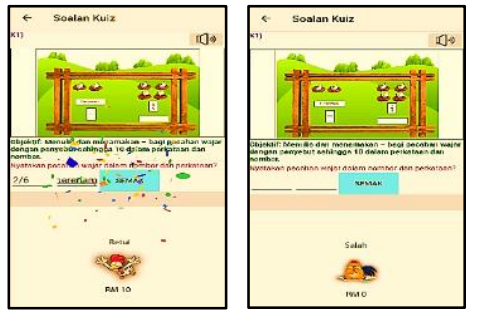

Figure 6: End Stage in The Game with Rewards

Before addressing the specifics of the game, the principal designer of the game (the researcher) attended rehearsals of the play for one month. Afterwards, the researcher designs a first draft of the game content. The game was developed after identifying the most important events of Copyright $\odot$ GLOBAL ACADEMIC EXCELLENCE (M) SDN BHD - All rights reserved 
the play according to the user's point of view and using multimedia methods to create the games. It is also supported by Gresalfi, Rittle-Johnson, Loehr and Nichols (2018), who believe that multimedia elements and visual elements are an exciting way of disseminating information and are a dynamic and effective medium for communicating information. The game content was iteratively revised, simplified and adapted to comply with the format and estimated duration (40 min) required for classroom use of the mobile application game.

The game was plotted to be a visual experience for few reasons, given this classification's solid fundamental narrative keystones (Khaddage \& Lattemann, 2016). The game also adjusts well to learning situations where problem-solving and critical and deductive reasoning is significant, and in conclusion, it is due to its capability to engage students. This mobile application game also comprises mini-games and puzzles to upsurge its playability. The researcher led a formative assessment session with students, and almost all the teachers engaged in the research. Teachers and students' responses assisted my experiment in discovering and fixing application faults, reforming the instructive game design and getting it better arranged to pursue among the most significant changes that the researcher made to the game because of this assessment. Assimilating all the quizzes a player must finish during the game in her topic levels. The player has the sense of playing a game as a replacement for thinking they are doing an exam masked as a mobile application game. Lastly, mini-games or tests embedded in the game were modified under the supervision of those responsible for the topic of the fraction so that the level was adapted to the needs of the students.

\section{Exam Assessment}

According to EMBI (2010), assessment in teaching and learning identifies student achievement in learning. The assessment used is a summative assessment aimed at measuring student achievement (SA) after learning whether students dominated the learning taught through the learning material itself (Lalley \& Gentile, 2009). Pre-test and post-tests were utilised in this research to assess student achievement (SA from now on) in fractional learning. The researchers constructed this assessment instrument and examined its content validity by a panel of two experienced secondary school teachers. All the informational content that a student would need to study to answer those questions was contained in the learning material of the fractions and the game (P-KSSMPKPS).

Therefore, this study uses a pre-test and post-test assessment test with subjective questions consisting of 19 items in Appendix A and B. This test method is done in writing using Bahasa Melayu language, where the pre-test items (Appendix A) and tests Post (Appendix B) is the same in terms of their contents. The difference between these two tests has a question-made question to show abnormalities, although the contents are still the same.

This study was initiated with a pre-test to determine students' existing knowledge of traditional methods before implementing learning treatment. The pre-test is important to determine the uniformity of the abilities and academic level of the elected students. In addition, the implementation of pre-tests can identify the problems and difficulties students face in learning the concept of fractions. After two weeks, pupils will undergo fractional learning treatments using the Mobile Game Education Application (P-KSSMPKPS) with traditional learning methods. The post-test was implemented after learning treatment was conducted to identify 
students' actual achievement in learning fractions. Implementation of pre and post-test instruments is described in Figure 7.



Figure 7: Research Design of P-KSSMPKPS Experiment

\section{Interviews}

The purpose of an interview conducted in this study was to know the views and interests of students in fractional topics based on the game-based mobile application of P-KSSMPKPS. In this study, this data is essential as students are always face-to-face with teachers in the learning process. It must also be emphasized their opinion in considering the aspects of improvement according to the time change. Hence, this effort is taken to know the problems and opinions of students on the existing learning methods and students' interests in learning using the Gamebased Mobile application of P-KSSMPKPS developed through this study.

Based on this view, this interview has questions that have been set up structured (Appendix C). If necessary, some additional questions for students will be spontaneously submitted, where this semi-structural interview method contains basic questions and additional questions to understand respondents' answers more profoundly (Vaismoradi, Jones \& Snelgrove, 2016; Kallio, Pietila, Johnson \& Kangasniemi, 2016). The interviews were conducted over two weeks. During this period, interviews were transcribed and analyzed using NVivo, a qualitative data analysis software programme. The researchers developed this evaluation instrument and subjected it to a panel of two experience university lectures to determine its content validity. 


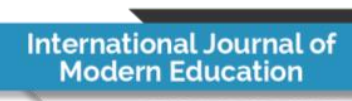

EISSN: 2637-0905

Volume 3 Issue 10 (September 2021) PP. 94-110

DOI: 10.35631/IJMOE.310008

Transcribing and coding did not take place at the end of the process. Rather than a sequential connection in which all interviews are performed first and then analyzed, the 'constant comparison' concept was employed (All, Castellar \& Van Looy, 2016). This method enabled us to conduct interviews until "category saturation" was achieved (Sutton \& Austin, 2015; Alam, 2020). The term saturation signals refer to the repetition of information and confirmation of established categories. Therefore, data collection was discontinued since no new codes were generated throughout the study. Ten semi-structured interviews were performed in total, deemed a sufficient sample size for the interviews (Adams, 2015).

The interviews were deductively analyzed, and the experts' responses and comments were coded in three stages (Azungah, 2018). In the first phase, transcriptions were coded at the most basic level. This process means that text segments were labelled using Nvivo coding (i.e., defining the text by a concept/term used by the interviewee). In a second coding phase, labels referring to similar content were grouped and conceptualized, creating categories (e.g., the similarity between conditions). These categories were attributed to dimensions of the study design (e.g., research design, participants, intervention, outcome measures and data analysis). An example of how coding occurred can be found in Table 6 .

\section{Results}

\section{Improving Students’ Achievement and The Fraction Knowledge}

In What Ways the Traditional Teaching Methods (Low-Grade Innovation) Improve Student's Achievement in Fraction Knowledge?

Table 2 shows that a significant difference was found between the pre-test $(\mathrm{M}=42.38, \mathrm{SD}=2.58)$ and post-test $(\mathrm{M}=44.76, \mathrm{SD}=2.58)$ in the control group $(t=-14.49, p<.001)$. It recommends that the incorporation of traditional instructional learning is favourable for students learning fractions.

Table 2: Pretest and Posttest Results for the Control Group

\begin{tabular}{lcccc}
\hline & $\mathbf{N}$ & Mean (M) & Std. Deviation (SD) & $\boldsymbol{t}$ \\
\hline Pretest & 76 & 42.38 & 2.582 & -14.49 \\
Posttest & 76 & 44.76 & 2.586 & \\
\hline
\end{tabular}

Note. ***P <.001.

In What Ways the Game-Based Mobile Application (P-KSSMPKPS) Remedial Instruction Improve Student's Achievement in Fraction Knowledge?

As shown in Table 3, after playing the game-based mobile application (P-KSSMPKPS), students' mean scores increased from 46.80 (pre-test) to 87.00 (post-test). A paired-sample ttest was performed to compare pre-and post-test results. A statistically significant difference was observed $(t=-73.22, p<.001)$. This result demonstrated that the game-based mobile application (P-KSSMPKPS) remedial instruction significantly improved student's achievement in fraction knowledge. 
Volume 3 Issue 10 (September 2021) PP. 94-110 DOI: 10.35631/IJMOE.310008

Table 3: Pretest and Posttest Results for the Experimental Group

\begin{tabular}{lcccc}
\hline & N & Mean (M) & Std. Deviation (SD) & $t$ \\
\hline Pretest & 76 & 46.80 & 4.397 & -73.22 \\
Posttest & 76 & 87.00 & 4.673 & \\
\hline Note. ***P $<001$ & & & &
\end{tabular}

\section{Comparing Educational Approaches Outcomes in the Enhancement of Remedial} Instruction

The following table summarises the analysis and comparison of pretest and posttest findings for the control and experimental groups.

\section{Comparison of Test Results Between the Two Groups Before the Use of Exercise}

According to the results in Table 4, the pretest scores for the experimental group and the control group were comparable $(\mathrm{t}=.43, \mathrm{p}=.35>.05)$, suggesting that students in both groups had comparable mathematical knowledge prior to the remedial learning activity.

Table 4: Independent Samples t-Test of The Pretest Assessment Scores

\begin{tabular}{lcccc}
\hline & N & Mean (M) & Std. Deviation (SD) & $t$ \\
\hline Control Group & 76 & 40.24 & 4.089 & -4.25 \\
Experimental Group & 76 & 46.80 & 4.397 & \\
\hline
\end{tabular}

Comparison of Test Results Between the Two Groups After the Use of Exercise According to the results in Table 5, there is a statistically significant difference in posttest scores between the experimental and control groups $(t=-1.81, \mathrm{p} .05)$. Additionally, the experimental group's mean posttest score was significantly higher than the control group's, suggesting that students who got remedial instruction via game-based mobile application (PKSSMPKPS) outperformed those who received teaching only through low-grade-technology.

Table 5: Independent Samples t-Test of The Posttest Assessment Scores

\begin{tabular}{lcccc}
\hline & N & Mean (M) & Std. Deviation (SD) & $\boldsymbol{t}$ \\
\hline Control Group & 76 & 42.61 & 2.618 & -3.97 \\
Experimental Group & 76 & 50.07 & 5.651 & \\
\hline
\end{tabular}

Interview of Students' Interest with The Game-Based Mobile Application (P-KSSMPKPS) According to the interview results in Table 6, all ten of the students pulled out for individual interviews commented on how much more they enjoyed fractions when it was taught in gamebased learning. The three major trends that arose from the interviews were problem-solving skills, student engagement, increased growth mindset. In terms of growth mindset, the students commented, "I am getting so much better at fraction now," and "I learned a lot about ordered fraction algebra. I did not know it was possible to learn fractions, but I understand so much more now on fractions." These comments show that the students have begun to view their fractions ability as fluid or developed through hard work and dedication. Many of the students who initially believed they were simply bad at fractions claimed in their interview that they now believe they can succeed with more fun and engaged practice. Another common theme that arose from the interviews was the problem-solving skills that were strengthened through 


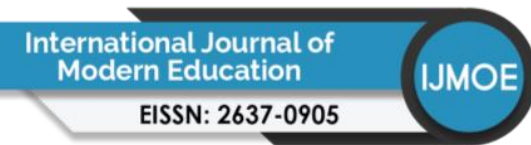

Volume 3 Issue 10 (September 2021) PP. 94-110

DOI: 10.35631/IJMOE.310008

game-based approaches to enhance remedial instruction. When asked if the students enjoyed working in game-based (P-KSSMPKPS), they once claimed, "Yeah, I enjoy working in PKSSMPKPS 'because I think differently from a lot of game software. So having learned from P-KSSMPKPS is great because if I think one way about something and they think a different way, we can put our ideas together and hopefully get something right." Many other students echoed this sentiment with comments such as, "I liked because there is a button favour in the shape of cartoon story like pizza shop, chicken shop and cake shop," and "I liked because there is a relief activity of acquiring me a fraction,"." The final common trend from student interviews was increased student engagement during various fractions activities. Some of the comments that expressed this sentiment were, "I feel good about using games to get motivated to learn fractions in a fun way," and "learning fractions is not my favourite but this week I loved it! Usually, I do not, but this week was great." Another student added, "learning fractions can sometimes be hard and stressful, and I have problems with stressing. When I get too stressed or worried, my ideas get bad, and that scares me." However, "this week made fractions feel like there was no pressure because everyone was having fun while they were learning". She mentioned that the game-based style of the fraction's lessons increased her interest and enjoyment of fractions and her willingness to try.

Table 6: Students Interview Result

\begin{tabular}{|c|c|c|c|c|c|c|}
\hline \multirow[b]{2}{*}{ Question } & \multicolumn{6}{|c|}{ Students Answer } \\
\hline & \multicolumn{3}{|c|}{$\begin{array}{c}\text { Game-Based Mobile App (P-KSSMPKPS) } \\
\text { (5 students) }\end{array}$} & \multicolumn{3}{|c|}{$\begin{array}{l}\text { Traditional Teaching Approach } \\
\text { (5 students) }\end{array}$} \\
\hline $\begin{array}{l}\text { 1.How far do you like to learn } \\
\text { mathematics? } \\
\text { a. Are you interested } \\
\text { in learning a } \\
\text { fractional topic? } \\
\text { b. Do you understand } \\
\text { the use of fractional } \\
\text { learning in } \\
\text { everyday life? }\end{array}$ & $\begin{array}{l}\text { - Like } \\
\text { ( } 2 \text { students) } \\
\text {-Remed } \\
\text { ( } 2 \text { students) } \\
\\
\text {-Yes, Understand } \\
\text { (2 students) }\end{array}$ & $\begin{array}{l}\text { - likes } \\
\text { (1 students) }\end{array}$ & $\begin{array}{l}\text { - Very like } \\
\text { (2 Students) }\end{array}$ & $\begin{array}{l}\text {-Boring } \\
\text { (2 students) } \\
\text {-Do Not Like } \\
\text { (2 students) } \\
\text {-Less Understand } \\
\text { (2 students) }\end{array}$ & $\begin{array}{l}\text {-Do Not Like } \\
\text { (2 students) } \\
\\
\text { Boring } \\
\text { (2 students) } \\
\text {-Understand } \\
\text { a little } \\
\text { (1 students) }\end{array}$ & $\begin{array}{r}\text { Less like } \\
\text { (1 Students) } \\
\\
\text { Not Interested } \\
\text { (1 Students) } \\
\\
\text { Do Not } \\
\text { Understand. } \\
\text { (2 Students) }\end{array}$ \\
\hline $\begin{array}{l}\text { a. How far current } \\
\text { teaching methods } \\
\text { are helpful for } \\
\text { learning fractions? }\end{array}$ & $\begin{array}{l}\text {-Yes. Easier } \\
\text { lot about } \\
\text { To answer } \\
\text { fraction } \\
\text { (1 students) }\end{array}$ & $\begin{array}{l}\text { Explore me } \\
\text { comprehend } \\
\text { (2 students) }\end{array}$ & $\begin{array}{l}\text { I learned a } \\
\text { ordered } \\
\text { algebra } \\
\text { (2 Students) }\end{array}$ & $\begin{array}{l}\text {-No, do not } \\
\text { Understand } \\
\text { help. } \\
\text { ( } 2 \text { students) }\end{array}$ & $\begin{array}{l}\text { No support } \\
\text { teaching } \\
\text { (1 students) }\end{array}$ & $\begin{array}{c}\text { Absent } \\
\text { learning } \\
\text { (2 Students) }\end{array}$ \\
\hline $\begin{array}{l}\text { 3. How far are you interested in } \\
\text { using these traditional methods } \\
\text { /game-based mobile app? } \\
\qquad \begin{array}{l}\text { a. Do you like to learn } \\
\text { a fractional topic } \\
\text { using these } \\
\text { traditional methods/ } \\
\text { mobile app? }\end{array}\end{array}$ & $\begin{array}{l}\text {-Yes love very } \\
\text { much } \\
\text { to } \\
\text { fraction. }\end{array}$ & $\begin{array}{c}\text { Yes, like } \\
\text { I understand so } \\
\text { much now }\end{array}$ & $\begin{array}{r}\text { I didn't know } \\
\text { It was posiible } \\
\text { learn }\end{array}$ & $\begin{array}{l}\text {-Do not like } \\
\text { ( } 2 \text { students) }\end{array}$ & $\begin{array}{l}\text { Don't llike } \\
\text { ( } 2 \text { students) }\end{array}$ & $\begin{array}{c}\text { No } \\
\text { (1 Students) }\end{array}$ \\
\hline
\end{tabular}


Volume 3 Issue 10 (September 2021) PP. 94-110 DOI: 10.35631/IJMOE.310008

\begin{tabular}{|c|c|c|c|c|c|c|}
\hline & $\begin{array}{l}\text { it } \\
\text { ( } 2 \text { students) }\end{array}$ & $\begin{array}{l}\text { On Fraction } \\
\text { ( } 1 \text { students) }\end{array}$ & $\begin{array}{l}\text { Realy like } \\
\text { (2 Students) }\end{array}$ & & & \\
\hline $\begin{array}{l}\text { 4. How far are you happy to } \\
\text { use these traditional } \\
\text { methods/mobile app? } \\
\text { a. Do you enjoy } \\
\text { learning a } \\
\text { fractional topic with } \\
\text { these traditional } \\
\text { methods/ mobile } \\
\text { app? }\end{array}$ & $\begin{array}{l}\text { - There is a Button } \\
\text { there } \\
\text { Favor in the shape } \\
\text { Of cartoon story } \\
\text { ( } 2 \text { students) } \\
\text {-Say fun learning } \\
\text { working } \\
\text { the concept of } \\
\text { because } \\
\text { fractional algebra } \\
\text { from } \\
\text { game } \\
\text { software } \\
\text { (1 students) }\end{array}$ & $\begin{array}{l}\text { Reason there is } \\
\text { story and the same } \\
\text { cartoon at outside } \\
\text { like pizza, Chicke } \\
\text { and cake } \\
\text { ( } 2 \text { students) } \\
\text { Fun learning } \\
\text { and engaged } \\
\text { engaged practice } \\
\text { (1 students) }\end{array}$ & $\begin{array}{c}\text { Cause } \\
\text { e story and } \\
\text { cartoon } \\
\text { (1 Students) } \\
\text { Yeah, I enjoy } \\
\text { working } \\
\text { its different } \\
\text { other } \\
\text { (3 Students)) }\end{array}$ & $\begin{array}{l}\text { Reason there is } \\
\text { understand } \\
\text { a picture cartoon } \\
\quad \text { only } \\
\\
\text { (2 students) }\end{array}$ & $\begin{array}{l}\text { fewer picture } \\
\text { attract } \\
\text { (2 students) }\end{array}$ & $\begin{array}{l}\text { res do not } \\
\text { picture that } \\
\text { given }\end{array}$ \\
\hline $\begin{array}{l}\text { 5. Does this traditional } \\
\text { methods/game-based mobile } \\
\text { application help you to solve } \\
\text { various fractional questions? }\end{array}$ & $\begin{array}{l}\text {-Children can play } \\
\text { can } \\
\text { pizza, sell chicker } \\
\text { understand } \\
\text { for juice } \\
\text { (2 students) } \\
\text { Students) }\end{array}$ & $\begin{array}{l}\text { Because there seen } \\
\text { to be a } \\
\text { of acquiring me a } \\
\text { fraction } \\
\text { ( } 2 \text { students) }\end{array}$ & $\begin{array}{r}\text { ms reasons } \\
\text { relief activity } \\
\text { fractions } \\
(1\end{array}$ & $\begin{array}{l}\text { Less attractive } \\
\text { reason the same } \\
\text { question is like } \\
\text { in class } \\
\text { ( } 2 \text { students) }\end{array}$ & $\begin{array}{l}\text { Reason for } \\
\text { noisy sounds } \\
\text { and unattractive } \\
\quad \text { pictures } \\
\text { (2 students) }\end{array}$ & $\begin{array}{c}\text { Don't } \\
\text { understand } \\
\text { fractional } \\
\text { questions } \\
\text { (1 Students) }\end{array}$ \\
\hline $\begin{array}{l}\text { 6. Do the components in the } \\
\text { game-based mobile } \\
\text { app/traditional methods make } \\
\text { it easier for you to understand } \\
\text { the fractional questions? }\end{array}$ & $\begin{array}{l}\text {-Ya. Easier to } \\
\text { easy } \\
\text { answer. } \\
\text { I love it } \\
\text { and great } \\
\text { he's } \\
\text { I'll } \\
\text { again. } \\
\text { (2 students) } \\
\end{array}$ & $\begin{array}{l}\text { Yes. I can } \\
\text { understand from } \\
\text { the story and } \\
\text { pictures given } \\
\text { questions starting } \\
\text { with it's a pleasure } \\
\text { (2 students) }\end{array}$ & $\begin{array}{c}\text { Yes. It's } \\
\text { to answer } \\
\text { because } \\
\text { there is a } \\
\text { picture if } \\
\text { wrong and } \\
\text { do it } \\
\text { (1 Students) }\end{array}$ & $\begin{array}{l}\text { No. } \\
\text { to } \\
\text { hard and } \\
\text { because } \\
\text { stressful } \\
\text { English }\end{array}$ & $\begin{array}{l}\text { It's not a } \\
\text { reason not to } \\
\text { understand } \\
\text { the question } \\
\text { (2 students) }\end{array}$ & $\begin{array}{r}\text { Its difficult } \\
\text { understand } \\
\text { of using } \\
\text { language } \\
\text { (1 Students) }\end{array}$ \\
\hline $\begin{array}{l}\text { 7. Does the cartoons / actual } \\
\text { picture / real picture help you to } \\
\text { understand the fractional } \\
\text { questions? }\end{array}$ & $\begin{array}{l}\text { Yes. The picture } \\
\text { is happy to see, } \\
\text { just like the } \\
\text { outside } \\
\text { the } \\
\text { algebra } \\
\text { (2 students) }\end{array}$ & $\begin{array}{l}\text { Yes. Same } \\
\text { story I've } \\
\text { ever been } \\
\text { through }\end{array}$ & $\begin{array}{l}\text { Yes I like the } \\
\text { story because } \\
\text { it's easy to } \\
\text { understand } \\
\text { fractional } \\
\text { (1 Students) }\end{array}$ & $\begin{array}{l}\text { - There is no } \\
\text { difficult story } \\
\text { gets } \\
\text { to understand } \\
\text { scares } \\
\\
\text { ( } 2 \text { students) }\end{array}$ & $\begin{array}{l}\text { Pictures don't } \\
\text { attract many words } \\
\text { don't understand } \\
\text { fractional } \\
\text { (2 students) }\end{array}$ & $\begin{array}{l}\text { Not helping } \\
\text { my idea } \\
\text { bad that } \\
\text { me } \\
\text { (1 Students) }\end{array}$ \\
\hline
\end{tabular}

\section{Discussion \& Conclusion}

The principal objective of this research was to evaluate the efficacy of game-based remedial education (P-KSSMPKPS) against low-grade technology in improving fractions performance. These findings corroborate earlier research (Hussain, Tan \& Idris, 2014; Hussain, Hoe \& Idris, 2017). This research established the efficacy of using multimedia devices, such as mobile application games, to assist students in learning fractions. Several prior studies examined the topic of game-based remedial education. Simsek (2016) proposed the Motion Math: Fraction, 


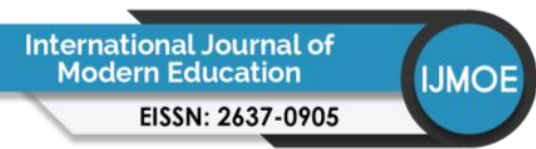

Volume 3 Issue 10 (September 2021) PP. 94-110

DOI: 10.35631/IJMOE.310008

a multiplayer environment designed to facilitate the peer-tutoring activities of Mathematics Learning Disabilities (MLD) to gain fraction skills, including comparison, estimation, and word problem solving related to remedial instruction. Four students with low achievement in mathematics engage in the study for few months, and their improvements demonstrated the effectiveness of this approach. Unlike the collaborative learning approach employed by Motion Math: Fraction, students in this study faced problem-solving situations independently. Students who participated in the P-KSSMPKPS game could not proceed without watching a selfexplanatory instruction game about the unit with which the students had difficulty. The students were asked to solve the problem before proceeding, which is the essence of fractions learning. Mobile applications game-based fractions learning can increase the level of proficiency when students study the unit on the "area of a circle." We found that integrating multimedia remedial instruction strategies with game-based learning provides more significant benefits for students learning fractions. When developed and designing digital games for educational purposes, it is essential to align the content and learning strategies with the game's structure (Chu, Chen \& Yang, 2016). To integrate fractions learning strategies more effectively into game-based remedial instruction, we split the learning material into several small-scale units to lessen the complexity of the individual task. In addition, digital games learning provides students with analytical information related to their learning outcomes in each task. This feedback enables students to monitor their learning and identify their weaknesses in each learning task. Furthermore, the multimedia experience and attractive graphics (essential elements of digital games) were fully utilized to magnify the experience of flow and engagement in the learning activities (Kwok, Ng, Ho, Ip \& Kui, 2020; Chen \& Wu, 2020). Finally, the researcher identifies several issues related to mobile applications game-based remedial instruction for future study. Investigating the effectiveness of mobile applications of game-based remedial instruction on learning motivation and attitudes related to fractions learning remains an important issue for future studies. A continuing study could be conducted to investigate the effectiveness of gamebased instruction for remedial purposes. It is requisite to determine whether game-based remedial instruction is suitable for other disciplines, such as language learning and vocational studies.

\section{Acknowledgments}

Thanks to the Perak State Education Department, the Perak District Education Office, teachers, and participating students. Thanks to all those involved.

\section{References}

Adams, W. C. (2015). Conducting semi-structured interviews. Handbook of practical program evaluation, 4, 492-505.

Akta 685, Akta Orang Kurang Upaya 2008.

Agrawal, J., \& Morin, L. L. (2016). Evidence-based practices: Applications of concrete representational abstract framework across math concepts for students with mathematics disabilities. Learning Disabilities Research \& Practice, 31(1), 34-44.

Alam, M. K. (2020). A systematic qualitative case study: Questions, data collection, NVivo analysis and saturation. Qualitative Research in Organizations and Management: An International Journal.

All, A., Castellar, E. P. N., \& Van Looy, J. (2016). Assessing the effectiveness of digital gamebased learning: Best practices. Computers \& Education, 92, 90-103. 


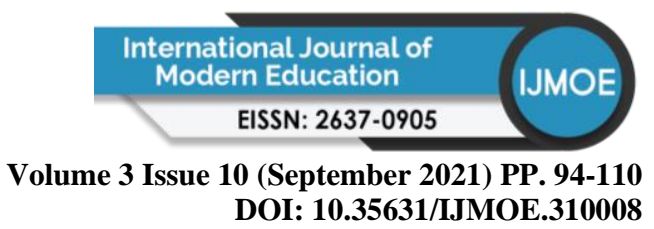

Allen, M.W. (2011). Designing successful e-learning: Forget what you know about instruction design and do something interesting (Vol.2). John Wiley \& Sons.

Amir, M. F., Hasanah, F. N., \& Musthofa, H. (2018). Interactive Multimedia Based Mathematics Problem Solving to Develop Student s' Reasoning. Int. J. Eng. Technol, 7(2.14), 272-276.

Anderson-Pence, K., \& Moyer-Packenham, P. S. (2015). Using Virtual Manipulatives to Enchance Collaborative Discourse in Mathematics Instruction.

Azungah, T. (2018). Qualitative research: deductive and inductive approaches to data analysis. Qualitative Research Journal.

Bengtsson, M. (2016). How to plan and perform a qualitative study using content analysis. NursingPlus Open, 2, 8-14.

Butterworth, B. (2013). Handbook of Mathematical Cognition: Chapter 26: Developmental Dyscalculia. Mathematical Cognition, 455-468.

Chen, C. L., \& Wu, C. C. (2020). Students' behavioral intention to use and achievements in ICT-Integrated mathematics remedial instruction: Case study of a calculus course. Computers \& Education, 145, 103740.

Chiu, T. K., \& Churchill, D. (2015). Exploring the characteristics of an optimal design of digital materials for concept learning in mathematics: Multimedia learning and variation theory. Computers \& Education, 82, 280-291.

Chu, H. C., Chen, J. M., \& Yang, S. M. (2016, September). Development of a game-based learning system based on the concept-effect model for improving mathematic learning achievements. In The International Workshop on Technology-Enhanced Collaborative Learning (TECL 2016) In conjunction with CRIWG/CollabTech 2016 (Vol. 1, p. 29).

Dennis, M. S., Knight, J., \& Jerman, O. (2016). Teaching high school students with learning disabilities to use model drawing strategy to solve fraction and percentage word problems. Preventing School Failure: Alternative Education for Children and Youth, 60(1), 10-21.

Echazarra, A., Salinas, D., Méndez, I., Denis, V., \& Rech, G. (2016). How teachers teach and students learn: Successful strategies for school.

Embi, M.A (2010). Panduan amalan Pengajaran \& Pembelajaran Berkesan.

Ervin, H. K. (2017). Fraction Multiplication and Division Models: A Practitioner Reference Paper. International Journal of Research in Education and Science, 3(1), 258-279.

Furlong, M., McLoughlin, F., McGilloway, S., Geary, D., \& Butterworth, B. (2015). Interventions to improve mathematical performance for children with mathematical learning difficulties (MLD). Cochrane Database of Systematic Reviews, 4.

Gresalfi, M. S., Rittle-Johnson, B., Loehr, A., \& Nichols, I. (2018). Design matters: explorations of content and design in fraction gemes. Educational Technology Research and Development, 66(3), 579-596.

Hakim, L. L., Alghadari, F., \& Widodo, S. A. (2019, October). Virtual manipulatives media in mathematical abstraction. In Journal of Physics: Conference Series (Vol. 1315, No. 1, p. 012017). IOP Publishing.

Hegedus, S., \& Moreno-Armella, L. (2020). Information and communication technology (ICT) affordances in mathemaeducation. Encyclopedia of Mathematics Education, 380-384.

Higgins, J. P., Green, S., \& Collaboration, C. (2008). Cochrane handbook for systematic reviews of interventions (Vol. 5). Wiley Online Librar. 


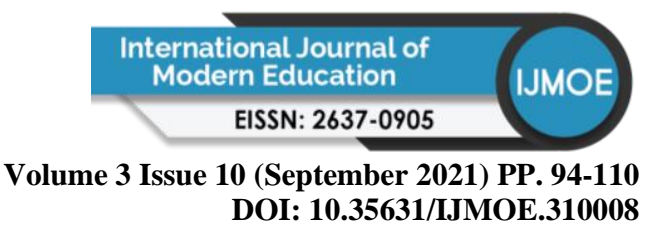

Hunt, J. H., Welch-Ptak, J. J., \& Silva, J. M. (2016). Initial understandings of fraction concepts evidenced by students with mathematics learning disabilities and difficulties: A framework. Learning Disability Quarterly, 39(4), 213-225.

Hussain, S. Y. S., Tan, W. H., \& Idris, M. Z. (2014). Digital game-based learning for remedial mathematics students: A new teaching and learning approach in Malaysia. International Journal of Multimedia Ubiquitous Engineering, 9(11), 325338.

Hussain, S. Y. B. S., Hoe, T. W., \& Idris, M. Z. B. (2017, May). Digital game-based learning: A new method in teaching and learning mathematics. In AIP Conference Proceedings (Vol. 1847, No. 1, p. 030016). AIP Publishing LLC.

Ikhwanudin, T., \& Suryadi, D. (2018). How Students with Mathematics Learning Disabilities Understands Fraction: A Case from the Indonesian Inclusive School. International Journal of Instruction, 11(3), 309-326

Khaddage, F., \& Lattemann, C. (2016). Towards mobilizing mathematics via gamification and mobile applications. Mobile Learning and STEM: Case Studies in Practice, 263.

Kwok, C. P., Ng, S. C., Ho, C. H., Ip, S. S., \& Kui, C. W. D. (2020, August). A Mobile GameBased Learning Approach for Motivating Preschoolers and Primary Students in Learning Mathematics. In International Conference on Technology in Education (pp. 35-45). Springer, Singapore.

Lalley, J. P., \& Gentile, J. R. (2009). Classroom assessment and grading to assure mastery. Theory Into Practice, 48, 28-35.

Lewis, K. E., \& Lynn, D. M. (2018). An insider's view of a mathematics learning disability: Compensating to gain access to fractions. Investigations in Mathematics Learning, 10(3), 159-172.

National Center for Learning Disabilities. Dyscalculia. (2014). Retrieved September 26, 2016, from http://www.ncld.org/glossary/dyscalculia

Nelson, G., Hunt, J. H., Martin, K., Patterson, B., \& Khounmeuang, A. (2020). Current knowledge and future directions: proportional reasoning interventions for students with learning disabilities and mathematics difficulties. Learning Disability Quarterly, 0731948720932850.

Rau, M. A., Aleven, V., \& Rummel, N. (2015). Successful learning with multiple graphical representations and self-explanation prompts. Journal of Educational Psychology, 107(1), 30.

Razak, R. A., \& Rahman, M. A. (2017). Pembinaan media pengajaran berasaskan multimedia di kalangan guru ICTL. JuKu: Jurnal Kurikulum \& Pengajaran Asia Pasifik, 1(2), 2031.

Rodrigues, J., Dyson, N. I., Hansen, N., \& Jordan, N. C. (2016). Preparing for algebra by building fraction sense. Teaching Exceptional Children, 49(2), 134-141.

Sharp, E., \& Shih Dennis, M. (2017). Model drawing strategy for fraction word problem solving of fourth-grade students with learning disabilities. Remedial and Special Education, 38(3), 181-192.

Shin, M., \& Bryant, D. P. (2015). Fraction interventions for students struggling to learn mathematics: A research synthesis. Remedial and Special Education, 36(6), 374-387.

Shin, M., \& Bryant, D. P. (2017). Improving the fraction word problem solving of students with mathematics learning disabilities: Interactive computer application. Remedial and Special Education, 38(2), 76-86. 
Volume 3 Issue 10 (September 2021) PP. 94-110 DOI: 10.35631/IJMOE.310008

Shin, M., Simmons, M., Meador, A., Goode, F., Deal, A., \& Jackson, T. (2021). Mathematics Instruction for Students with Disabilities: Applied Examples Using Virtual Manipulatives.

Simon, M. A., Kara, M., Norton, A., \& Placa, N. (2018). Fostering construction of a meaning for multiplication that subsumes whole-number and fraction multiplication: A study of the Learning Through Activity research program. The Journal of Mathematical Behavior, 52, 151-173.

Simsek, O. (2016). Use of a game-based app as a learning tool for students with mathematics learning disabilities to increase fraction knowledge/skill (Doctoral dissertation, University of South Florida).

Sumpter, L., \& Eriksson, H. (2021). Algebraic and fractional thinking in collective mathematical reasoning. Educational Studies in Mathematics.

Sutaji, S. S. (2015). Kesan penggunaan koswer multimedia animasi visual terhadap pencapaian dalam an matematik (Doctoral dissertation, Universiti Tun Hussein Onn Malaysia).

Sutton, J., \& Austin, Z. (2015). Qualitative research: Data collection, analysis, and management. The Canadian journal of hospital pharmacy, 68(3), 226.

Vaismoradi, M., Jones, J., Turunen, H., \& Snelgrove, S. (2016). Theme development in qualitative content analysis and thematic analysis.

Yang, D. C., \& Sianturi, I. A. J. (2020). Analysis of algebraic problems intended for elementary graders in Finland, Indonesia, Malaysia, Singapore, and Taiwan. Educational Studies, $1-23$.

Yang, D. C. (2018). Study of fractions in elementary mathematics textbooks from Finland and Taiwan. Educational Studies, 44(2), 190-211.

Zaibon, S. B. (2015). User testing on game usability, mobility, playability, and learning content of mobile game-based learning. Jurnal Teknologi, 3, 57-61.

Zhang, Y., \& Zhou, X. (2016). Building knowledge structures by testing helps children with mathematical learning difficulty. Journal of Learning Disabilities, 49(2), 166-175. 